\title{
PHÂN VÙNG HIỂM HỌA LŨ LỤT DO MƯA LỚN TRÊN LỤC ĐỊA KẾT HỢP VỚI MỰC NƯớC BIỂN DÂNG LUUU VỰC SÔNG VU GIA THU BỒN
}

\author{
Trương Vân Anh", Hoàng Thanh Sơnn ${ }^{2}$
}

Tóm tắt: Vu Gia Thu Bồn là luu vục sông lớn nhất miền Trung, với địa hình dốc ở miền núi, mạng luới sông suối phát triển phân nhiều nhánh làm cho mưc độ tập trung nước mưa lớn cả về tổng lượng lẫn cuờng độ trên phạm vi rộng và khi đổ về hạ du có địa hình thấp trũng, thường làm ngập lut cả vùng đồng bằng gây nên nhũng thiệt hại nghiêm trọng về người và của. Do đó việc phân vùng hiểm họa lũ lụt ở đây ý nghĩa đặc biệt quan trọng trong công tác phòng chống thiên tai do lũ lụ gây ra. Bài báo này sẽ xác định cấp độ hiểm họa lũ lut do mưa lớn kết hợp với mục nước biển dâng cho lưu vưc sông Vu Gia Thu Bồn. Phưong pháp mô hình toán kết hợp với GIS sẽ được sử dụng để xây dụng bản đồ hiểm họa lũ lụt cho lưu vực nghiên cứu. Theo đó $30 \%$ diện tích vùng đồng bằng thuộc cấp độ hiểm họa cao và rất cao, $5 \%$ thuộc cấp độ hiểm họa trung bình và $2 \%$ thuộc cấp độ hiểm họa thấp và rất thấp. Kết quả này là cơ sở để các nhà ra quyết định đưa ra nhũng chiến lược phát triển phù hợp cũng nhu các phuơng án úng phó khẩn cấp với lũ lụt để có thể giảm tối đa thiệt hại về người và của do lũ lụt gây ra.

Từ khóa: Rủi ro thiên tai, hiểm họa lũ lụt, Vu Gia Thu Bồn, cấp độ hiểm họa.

Ban Biên tập nhận bài: 15/7/2019; Ngày phản biện xong: 12/8/2019; Ngày đăng bài: 25/9/2019

\section{Giới thiệu chung}

Hiểm họa là khả năng xuất hiện các hiện tượng tự nhiên hoặc do con người gây ra, có thể gây thương tật, chết người hoặc ảnh hưởng sức khỏe, làm hư hại hoặc mất mát tài sản, cơ sở hạ tầng, sinh kế, cung cấp dịch vụ và tài nguyên môi trường [1]. Theo đó cấp độ hiểm họa của một đối tượng là khả năng gặp hiểm họa của đối tượng đó trong tương lai. Nếu một đối tượng có cấp độ hiểm họa thấp thì đối tượng đó ít có khả năng gặp hiểm họa, ngược lại, một đối tượng có cấp độ hiểm họa cao có nghĩa là nó có nhiều khả năng phải đối mặt hiểm họa trong tương lai.

Lũ lụt vốn được coi là một hiện tượng cực đoan có thể gây thiệt hại lớn nhất về người và của [10]. Như vậy, lũ lụt cũng có thể tạo nên các điều kiện hiểm họa đến cộng đồng và môi trường. Hiểm họa lũ lụt là khả năng thiệt hại về người và của gây nên bởi các hiện tượng lũ lụt trong tương lai. Cấp độ hiểm họa lũ thay đổi theo độ lớn của các trận lũ và bị ảnh hưởng bởi thuộc tính của trận lũ đó, địa hình vùng phơi lộ và các kế hoạch ứng cứu khẩn cấp [2,5]. Từ đó bản đồ hiểm họa lũ lụt được xây dựng như là một công cụ hỗ trợ xác định các cấp độ hiểm họa của các ô lưới trên bản đồ [3]. Đây có thể coi là một công cụ đơn giản, nhanh và dễ hiểu phục vụ ngăn ngừa và quản lý hiểm họa lũ lụt hiện đang được cộng đồng toàn cầu sử dụng rộng rãi [4] .

Ở Việt Nam khi nghiên cứu về hiểm họa lũ lụt, người ta thường tập trung xây dựng các bản đồ ngập lụt ứng với các trận lũ thiết kế khác nhau [6-9]. Điều này gây khó khăn cho các nhà ra quyết định do có quá nhiều bản đồ ngập lụt và những thông tin xung quanh để dựa vào đó đưa ra các quyết định quy hoạch phát triển chiến lược hay phương án ứng cứu của từng vùng. Ngược lại, nếu có một bản đồ cấp độ hiểm họa của một vùng thì các cấp có thẩm quyền sẽ dễ dàng xác định được các việc cần phải triển khai thực hiện đối với vùng đó để phòng chống hiểm họa lũ lụt trong tương lai.

${ }^{1}$ Trường Đại học tài nguyên và Môi trường Hà Nội

2 Viện Dịa lý

Email: tvanh@hunre.edu.vn; hoangson97@gmail.com 


\section{BÀI BÁO KHOA HỌC}

Bài báo này đề xuất phương pháp xác định hiểm họa lũ lụt gây nên do mưa lớn kết hợp với mực nước biển dâng do bão cho hạ lưu lưu vực sông Vu Gia Thu Bồn, một lưu vực sông miền Trung hàng năm có khoảng 15 trận lũ lớn bé với mức thiệt hại bình quân năm khoảng vài trăm tỷ đồng (Quang Nam, 2014). Phương pháp mô hình toán kết hợp GIS sẽ hỗ trợ cho việc mô phỏng và bản đồ hóa hiểm họa ngập lụt cho toàn vùng đồng bằng phơi lộ với lũ lụt của vùng nghiên cứu.

\section{Phương pháp nghiên cứu và thu thập tài liệu}

\subsection{Giới thiệu về khu vục nghiên cứu}

Vu Gia Thu Bồn là lưu vực sông lớn nhất ở miền Trung Việt Nam bao trùm 2 tỉnh là Đà Năng, Quảng Nam và một phần nhỏ của tỉnh KonTum. Lưu vực có diện tích $10350 \mathrm{~km} 2$ thu nước từ phía Đông của dãy Trường Sơn rồi đổ ra biển qua cửa Hàn (Đà Nẵng) và Cửa Đại (Hội An). Hai con sông chính trong hệ thống là sông Vu Gia và Thu Bồn chảy qua các địa hình phức tạp từ những dãy núi hẹp và dốc đến vùng đồng bằng thấp trũng ven biển nên ngập lụt thường xuyên xảy ra ở vùng hạ du này (Hình 1 ).

Khí hậu ở đây bị chi phối bởi chế độ nhiệt đới gió mùa vì vậy đặc tính của mưa ở vùng này rất phức tạp. Mưa thường năm trong khoảng từ $2000-4000 \mathrm{~mm} /$ năm với khoảng 65 - 80\% tổng lượng mưa phân bố trong mùa mưa từ tháng 9 tháng 12. Trung bình hàng năm ở đây đón từ 2 4 trận bão gây nên ngập lụt nghiêm trọng vùng hạ du do ảnh hưởng của hoàn lưu bão và nước biển dâng. Để nghiên cứu ảnh hưởng của mưa, 15 trạm khí tượng và thủy văn được xây dựng và vận hành trên lưu vực để thu thập số liệu khí tượng và dòng chảy (Hình 2).

Vu Gia Thu Bồn cũng là lưu vực có các trung tâm du lịch và phát triển kinh tế của cả vùng ven biển miền trung Việt Nam với 2 thành phố du lịch lớn là Đà Nẵng và Hội An. Ngoài ra phát triển công nghiệp đang diễn ra mạnh mẽ ở Quảng Nam. Cả hai ngành này đều bị ảnh hưởng bởi các loại hình thiên tai như bão và lũ lụt. Thiệt hại hàng năm do lũ lụt ở Quảng Nam ước tính khoảng 6,26\% giá trị GDP của tỉnh. Do đó việc xác định được bản đồ hiểm họa lũ lụt ở đây có ý nghĩa rất quan trọng trong việc định hướng phát triển bền vững kinh tế xã hội cũng như an toàn cuộc sống của các cộng đồng dân cư trên lưu vực.

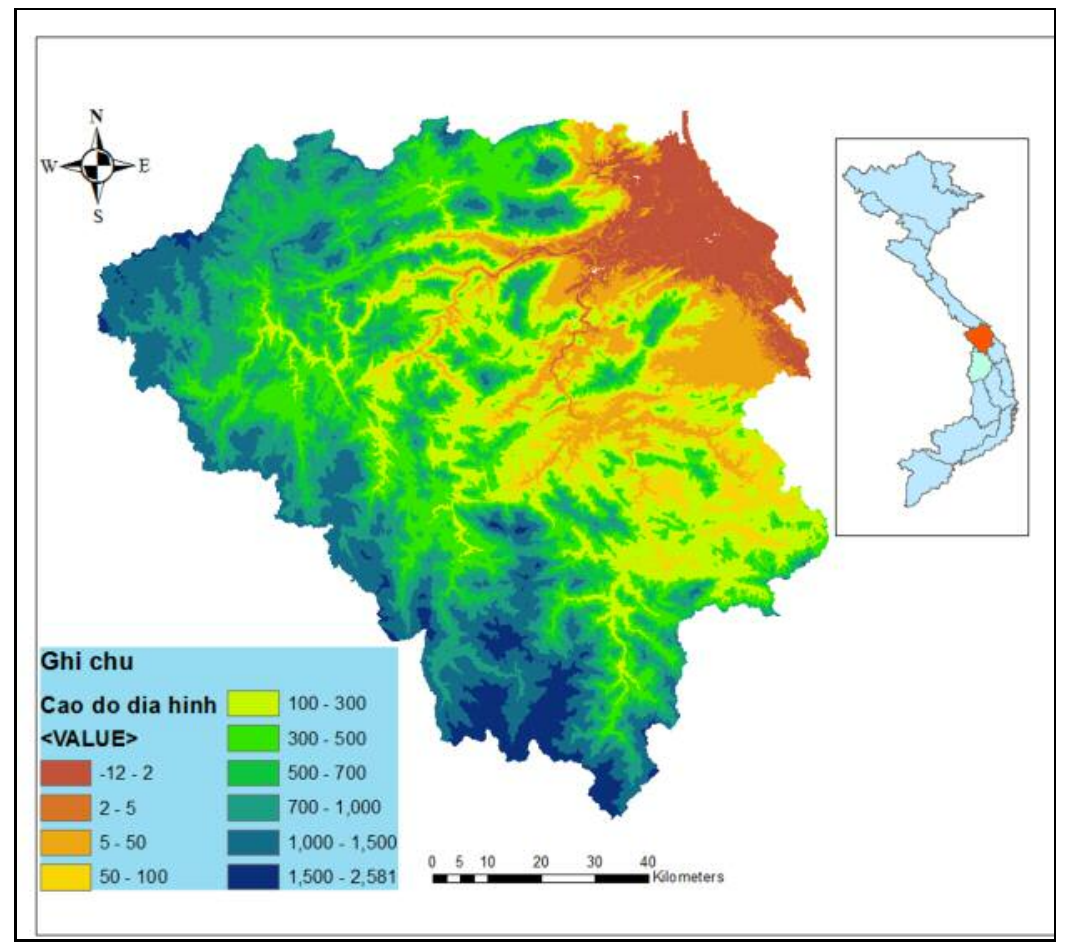

Hình 1. Địa hình lưu vực sông Vu Gia Thu Bồn 


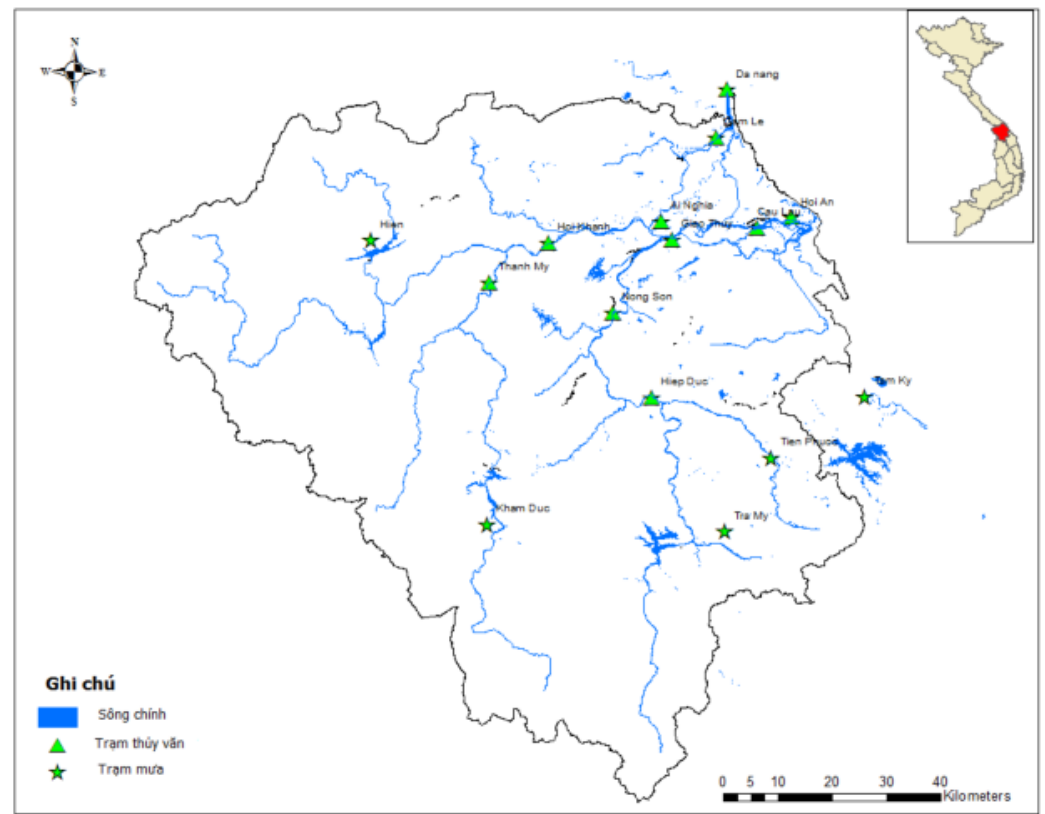

Hình 2. Mạng lưới trạm khí tượng thủy văn Lưu vục sông Vu Gia Thu Bồn

\subsection{Phwơng pháp nghiên cúu}

\subsubsection{Giới thiệu về mô hình MIKE}

Mô hình MIKE là bộ mô hình về tài nguyên nước do viện Thủy Lực Đan Mạch xây dựng. Bộ mô hình gồm rất nhiều mô hình nhỏ giúp mô phỏng các quá trình thủy văn, thủy động lực học, vân chuyển bùn cát, chất lượng nước,... trong đó mô hình MIKE NAM là mô hình mưa rào - dòng chảy dạng tất định, thông số tập trung, giúp mô phỏng quá trình dòng chảy tại cửa ra các tiểu lưu vực sông [12]. Hiện nay mô hình này đang được ứng dụng rộng rãi ở Việt Nam [6, 7, 8, 9, 11, 16]. Mô hình này được sử dụng để mô phỏng quá trình dòng chảy từ mưa các lưu vực thượng nguồn vùng nghiên cứu, làm đầu vào cho mô hình lan truyền sóng lũ trong sông.

Mô hình MIKE 11 là mô hình thủy động lực học 1 chiều giúp mô phỏng lan truyền sóng lũ trong sông [12]. Mô hình này được sử dụng rộng rãi trong các bài toán về lũ lụt và xâm nhập mặn cho các hệ thống sông ở Việt Nam [6, 7, 8, 9, 15].

Mô hình MIKE 21 là một công cụ giúp mô phỏng các quá trình thủy lực vùng cửa sông ven biển [13]. Nó được kết nối với MIKE 11 thông qua mô hình MIKE FLOOD [14] để mô phỏng ngập lụt vùng đồng bằng thấp trũng lưu vực sông Vu Gia Thu Bồn.

2.2.2. Thiết lập mô hình lũ cho lưu vưc sông Vu Gia Thu Bồn

2.2.2.1. Phân chia tiểu lưu vục phục vu mô phỏng mô hình MIKE NAM

Vùng nghiên cứu là toàn bộ lưu vực sông $\mathrm{Vu}$ Gia Thu Bồn, được chia thành 30 tiểu lưu vực (hình 3 ) hứng và tiếp nước cho mạng lưới thủy lực sông ngòi tính từ Thành Mỹ (trên sông $\mathrm{Vu}$ Gia) và Nông Sơn (trên sông Thu Bồn) ra đến biển (hình 3 ).

Mô hình MIKE NAM sẽ được xây dựng để tính toán dòng chảy từ các tiểu lưu vực này từ các trận mưa thiết kế và kết quả của nó sẽ là đầu vào cho mô hình lan truyền sóng lũ trên sông và vùng đồng bằng (MIKE 11 và MIKE 21).

\subsubsection{Thiết lập mô hình MIKE 11}

MIKE 11 được thiết lập cho mạng lưới sông từ Thành Mỹ và Nông Sơn ra đến cửa Hàn và cửa Đại (hình 4). 


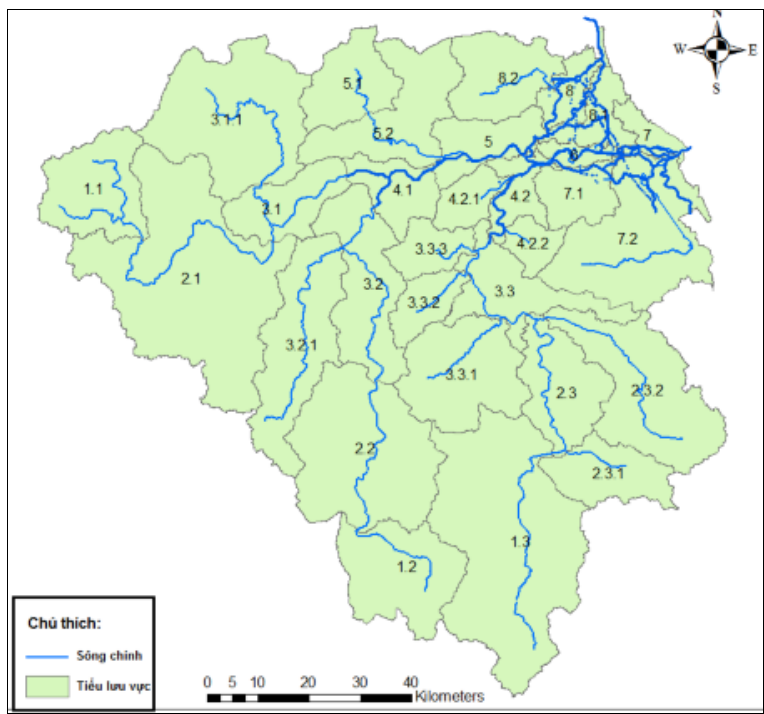

Hình 3. Tiểu lưu vực sông Vu Gia - Thu Bồn

2.2.2.3. Thiết lập mô hình MIKE 21 - MIKE FLOOD

Mô hình MIKE 11 sau khi được thiết lập sẽ được kết nối với lưới địa hình của mô hình MIKE 21 thiết lập cho vùng đồng bằng trong MIKE FLOOD để mô phỏng quá trình lan truyền sóng lũ trong sông và vùng đồng bằng ngập lũ [hình 5]. Mô hình này sẽ được sử dụng để mô phỏng ngập lụt vùng hạ du theo các kịch bản dòng chảy được tính toán từ mô hình MIKE NAM và kịch bản mực nước biển dâng như trình bày ở bảng 1 .

\subsubsection{Xây dựng kịch bản lũ}

Để xác định được bản đồ hiểm họa, các kịch

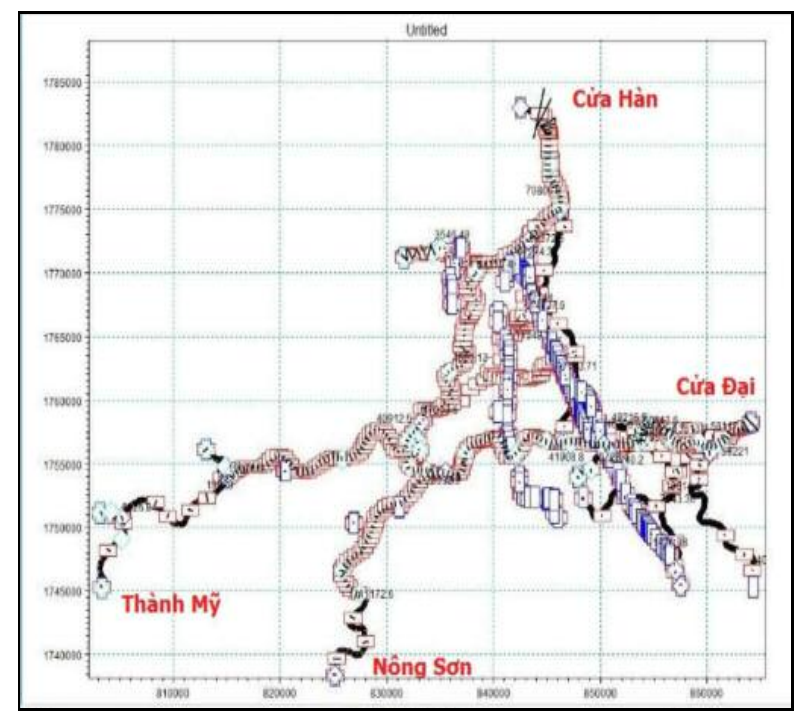

Hình 4. Mạng luoói sông được mô hình hóa bằng MIKE 11

bản lũ được thiết kế cho phù hợp với mục đích nghiên cứu. Trong bài báo này, kịch bản lũ sẽ là sự kết hợp giữa các trận mưa thiết kế theo tần suất trên lưu vực và mực nước biển thiết kế theo tần suất tại hai cửa sông là Cửa Hàn và Cửa Đại. 5 kịch bản lũ được thiết kế như bảng 1 .

Các kịch bản này sẽ được mô phỏng bằng bộ mô hình MIKE đã được hiệu chỉnh và kiểm định cho toàn vùng nghiên cứu. Sau đó các bản đồ ngập lụt tương ứng với từng kịch bản được phân tích để đưa ra được bản đồ hiểm họa lũ lụt lưu vực sông. Sơ đồ tính toán được thể hiện ở hình 6.

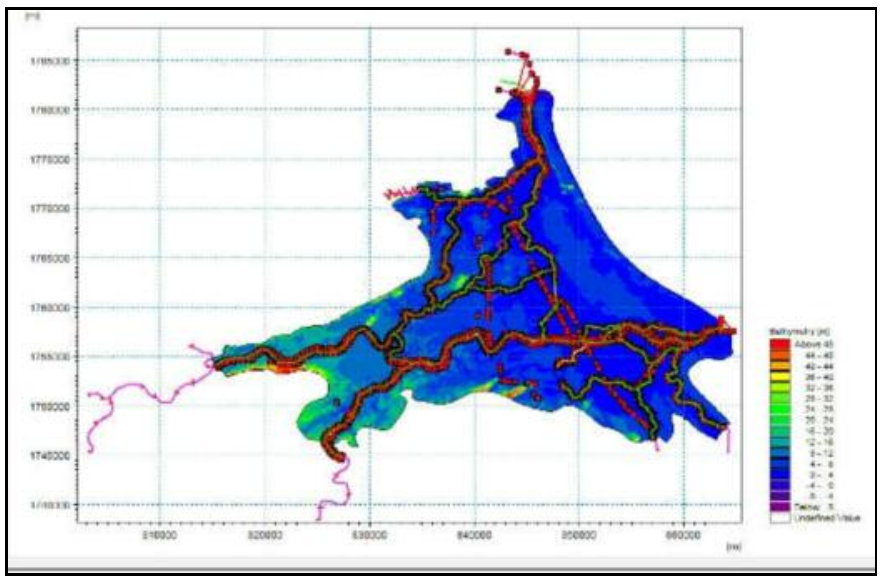

Hình 5. Kết nối lưới sông (MIKE 11) và lưới địa hình (MIKE 21) trong MIKE FLOOD 
Bảng 1. Các kịch bản lũ thiết kế phục vu nghiên cứu bản đồ hiểm họa lũ

\begin{tabular}{cccc}
\hline \multirow{2}{*}{ Kịch bản } & \multicolumn{2}{c}{ Trận Mưa thiết kế } & $\begin{array}{c}\text { Mực nước } \\
\text { Biền thiết kế }\end{array}$ \\
\cline { 2 - 3 } & Tần suất & Thời kỳ lặp lại & \\
KB1 & $20 \%$ & 5 năm & Triều cường \\
KB2 & $10 \%$ & 10 năm & $1 \%$ \\
KB3 & $5 \%$ & 20 năm & $2 \%$ \\
KB4 & $2 \%$ & 50 năm & $5 \%$ \\
KB5 & $1 \%$ & 100 năm & $10 \%$ \\
\hline
\end{tabular}

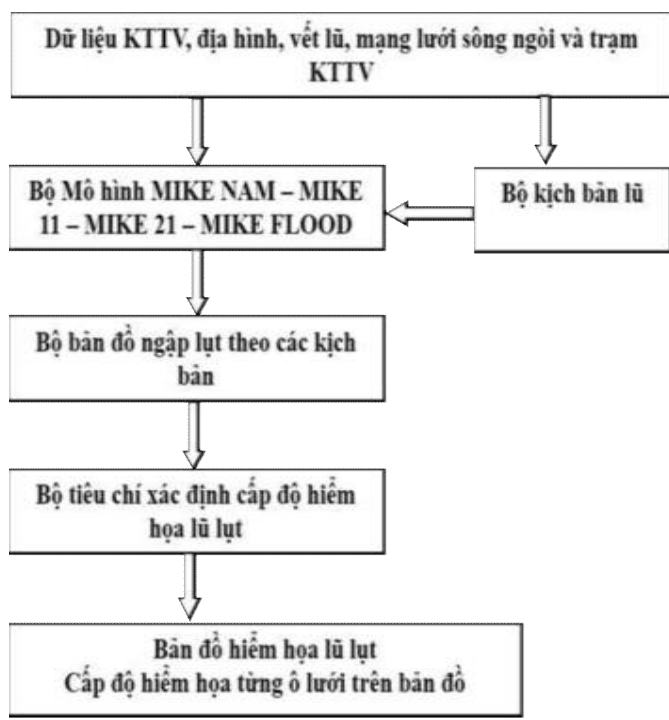

Hình 6. So đồ nghiên cưu

\subsubsection{Bộ tiêu chí xác định cấp độ hiểm họa lũ lut}

Trong nghiên cứu này, cấp độ hiểm họa lũ lụt được gán cho từng vùng dựa vào khả năng bị lũ lụt của từng ô lưới trên bản đồ. Nếu một vùng thường xuyên bị ngập lụt thì vùng đó có cấp độ hiểm họa lũ lụt cao và ngược lại, nếu vùng đó rất ít khi bị ngập lụt, vùng đó có cấp độ hiểm họa thấp.

Cấp độ hiểm họa trong nghiên cứu này được xây dựng dựa trên kết quả của các nghiên cứu gần đây $[16,17,18,19,20]$ và từ kinh nghiệm của tác giả xem xét các điều kiện trên lưu vực sông cũng như kết quả mô phỏng mô hình. Theo đó 5 thang cấp độ hiểm họa được xác định với các tiêu chí ở bảng 2 .
Bảng 2. Tiêu chíxác định cấp độ hiểm họa lũ lut vùng nghiên cứu

\begin{tabular}{|c|c|c|c|}
\hline Cấp độ hiểm họa & $\begin{array}{l}\text { Ký } \\
\text { hiệu }\end{array}$ & $\begin{array}{l}\text { KB } \\
\text { lũ }\end{array}$ & Mô tả \\
\hline $\begin{array}{l}\text { 1. Hiểm họa rất } \\
\text { cao }\end{array}$ & H5 & KB1 & $\begin{array}{l}\text { Vùng rất } \\
\text { thường xuyên } \\
\text { bị ngập lụt }\end{array}$ \\
\hline 2. Hiểm họa cao & $\mathrm{H} 4$ & KB2 & $\begin{array}{l}\text { Vùng thường } \\
\text { xuyên bị ngập } \\
\text { lụt }\end{array}$ \\
\hline $\begin{array}{l}\text { 3. Hiểm họa } \\
\text { trung bình }\end{array}$ & $\mathrm{H} 3$ & KB3 & $\begin{array}{l}\text { Vùng thỉnh } \\
\text { thoảng bị ngập } \\
\text { lụt }\end{array}$ \\
\hline 4. Hiểm họa thấp & $\mathrm{H} 2$ & KB4 & $\begin{array}{l}\text { Hiếm khi bị } \\
\text { ngâp lut }\end{array}$ \\
\hline $\begin{array}{l}\text { 5. Hiểm họa rất } \\
\text { thấp }\end{array}$ & H1 & KB5 & $\begin{array}{l}\text { Hầu nhu } \\
\text { không bị ngập } \\
\text { lụt }\end{array}$ \\
\hline
\end{tabular}

\section{Kết quả và thảo luận}

\subsection{Hiệu chỉnh và kiểm định mô hình MIKE NAM}

Mô hình MIKE NAM được thiết lập cho 30 tiểu lưu vực trên. Do chỉ có 2 trạm đo lưu lượng trên lưu vực là Nông Sơn và Thành Mỹ nên mô hình được hiệu chỉnh và kiểm định cho 2 tiểu lưu vực này trong 2 trận lũ lớn vào cuối tháng 9 đầu 10 năm 2007 và 2009. Kết quả tương đối tốt như thể hiện ở bảng 3 .

Bộ thông số sau kiểm định của 2 mô hình này được áp dụng cho các tiểu lưu vực tương tự để có thể mô phỏng được dòng chảy từ mưa.

\subsection{Hiệu chỉnh, kiểm định mô hình MIKE FLOOD}

Mô hình này đã được hiệu chỉnh và kiểm định bằng số liệu thực đo của trận lũ 2007 và 2009 trên một số vị trí khống chế như Giao Thủy, Ái 


\section{BÀI BÁO KHOA HỌC}

Nghĩa, Câu Lâu và Cẩm Lệ (Bảng 4) và một số vết lũ của trận lũ năm 2009 thu thập được rải rác trên vùng đồng bằng ngập lũ (Hình 7). Kết quả là khá tốt, đảm bảo bộ thông số của mô hình thủy lực 1 chiều và 2 chiều có thể được sử dụng để mô phỏng ngập lụt vùng nghiên cứu.

Bảng 3. Kết quả hiệu chỉnh và kiểm định mô hình MIKE NAM

\begin{tabular}{lllll}
\hline \multirow{2}{*}{ Tiểu lưu vực } & Hệ số Nash & \multicolumn{3}{c}{ Hệ số tương quan R } \\
\cline { 2 - 5 } & Năm 2007 & Năm 2009 & Năm 2007 & Năm 2009 \\
\hline Nông Sơn & 0,97 & 0,96 & 0,97 & 0,94 \\
Thành Mỹ & 0,96 & 0,81 & 0,96 & 0,96 \\
\hline
\end{tabular}

Bảng 4. Kết quả hiệu chỉnh và kiểm định mô hình

\begin{tabular}{|c|c|c|c|c|c|c|c|}
\hline \multirow{2}{*}{ STT } & \multirow{2}{*}{ Tên trạm } & \multirow{2}{*}{ Sông } & \multicolumn{3}{|c|}{$\begin{array}{c}\text { Hiệu chỉnh } \\
\text { với trận lũ năm } 2009\end{array}$} & \multicolumn{2}{|c|}{$\begin{array}{c}\text { Kiểm định } \\
\text { với trận lũ năm } 2007\end{array}$} \\
\hline & & & $\begin{array}{l}\text { Chỉ } \\
\text { Nash }\end{array}$ & số & Đánh giá & $\begin{array}{l}\text { Chỉ số } \\
\text { Nash }\end{array}$ & Đánh giá \\
\hline 1 & Ái Nghĩa & Vu Gia & 0,89 & & Tốt & 0,86 & Tốt \\
\hline 2 & Cẩm Lệ & Vu Gia & 0,85 & & Tốt & 0,85 & Tốt \\
\hline 3 & Giao Thủy & Thu Bồn & 0,90 & & Tốt & 0,90 & Tốt \\
\hline 4 & Câu Lâu & Thu Bồn & 0,86 & & Tốt & 0,87 & Tốt \\
\hline
\end{tabular}

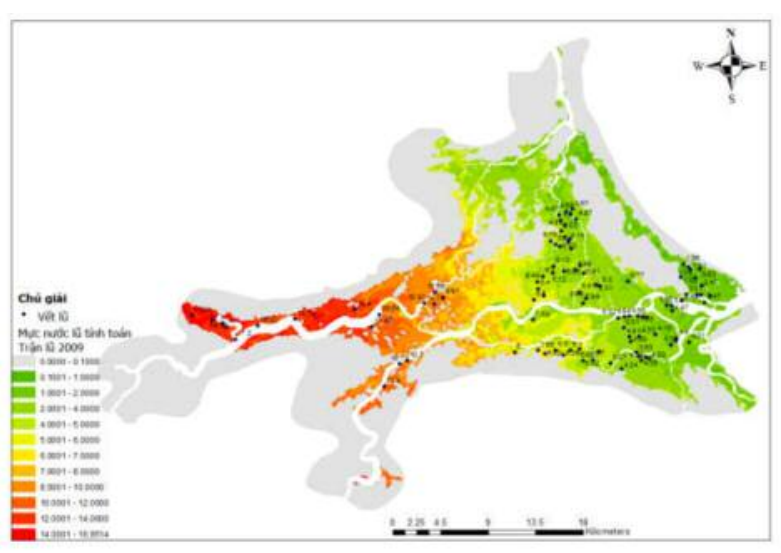

Hình 7. So sánh vêt lũ và mô phỏng trận lũ năm 2009

\subsection{Mô phỏng ngập lụt}

Sau khi đã có bộ thông số được kiểm định của mô hình lũ, các kịch bản lũ được mô phỏng và phân tích.

Kết quả cho thấy ngay cả với trận mưa 50\% kết hợp với triều cường, vùng hạ du VGTB đã có những điểm ngập cục bộ (Hình 8). Theo kết quả mô phỏng, đây thường là những vùng đất trũng, phân bổ ở các huyện vùng đồng bằng thấp trũng trong đó ba huyện Quế Sơn, Điện Bàn, Duy Xuyên tỉnh Quảng Nam là ngập nặng nhất, với trên dưới $40 \%$ diện tích của các huyện chìm trong nước. Tiếp đến là Hội An, Thăng Bình, Đại Lộc tỉnh Quảng Nam và Hòa Vang, Ngũ Hành Sơn của Đà Nẵng đều có diện ngập xấp xỉ $20 \%$. Độ ngập sâu trung bình khoảng $1 \mathrm{~m}$ và ngập úng cục bộ này một phần gây ra bởi hệ thống đường giao thông chia cắt tuyến thoát lũ.

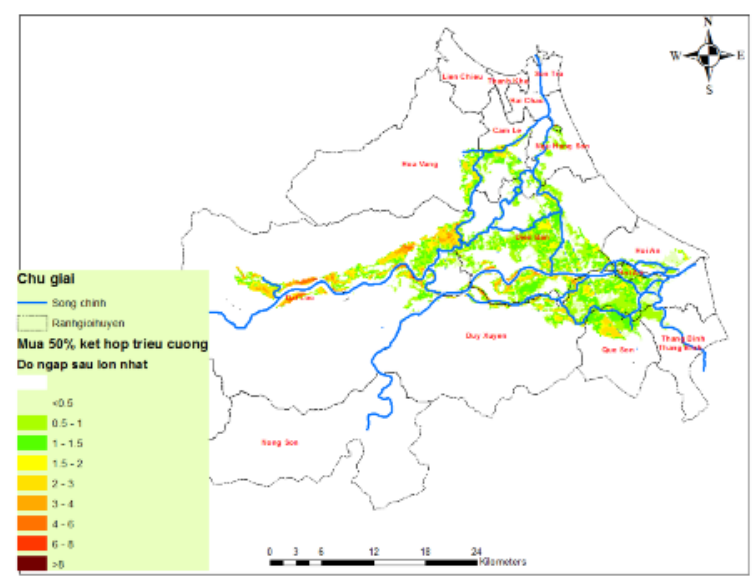

Hình 8. Độ ngập sâu lón nhất kịch bản mura tần suất $50 \%$ kết hơp triều cường

Kết quả kịch bản mưa 20\% kết hợp với triều cường (KB1) cho thấy diện ngập đã tăng lên gần 1.5 lần (từ khoảng 23860ha lên khoảng 33660 ha) (hình 9). Đây chính là kịch bản phân vùng có hiểm họa rất cao, các xã có diện tích nằm 
trong vùng ngập do kịch bản này gây ra sẽ được gán mức độ hiểm họa $\mathrm{H} 4$. Hệ thống đường giao thông ở đây, đặc biệt tuyến đường quốc lộ $1 \mathrm{~A}$ đã gây ngập sâu ở thượng nguồn và ngăn không có lũ tiêu thoát về hạ du. Mức ngập sâu phổ biến đã tăng lên $2 \mathrm{~m}$.

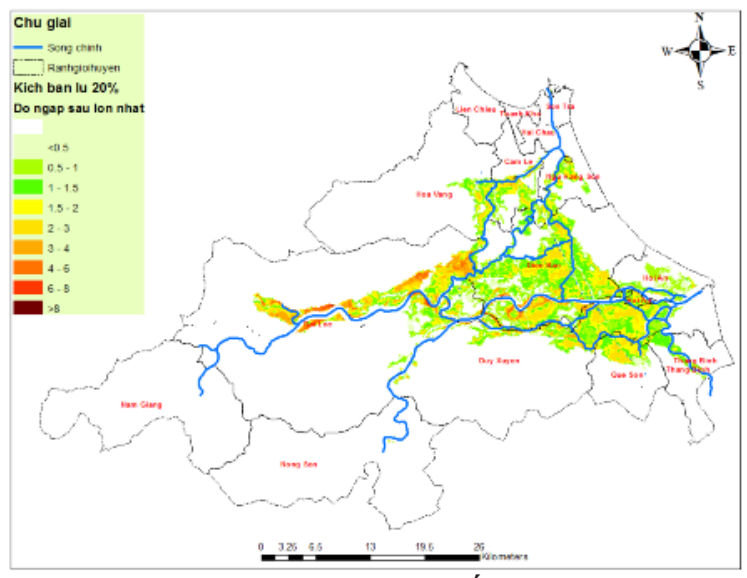

Hình 9. Độ ngập sâu lớn nhất kịch bản mua tần suất 20\% kết hơp triều cuòng (KB1)

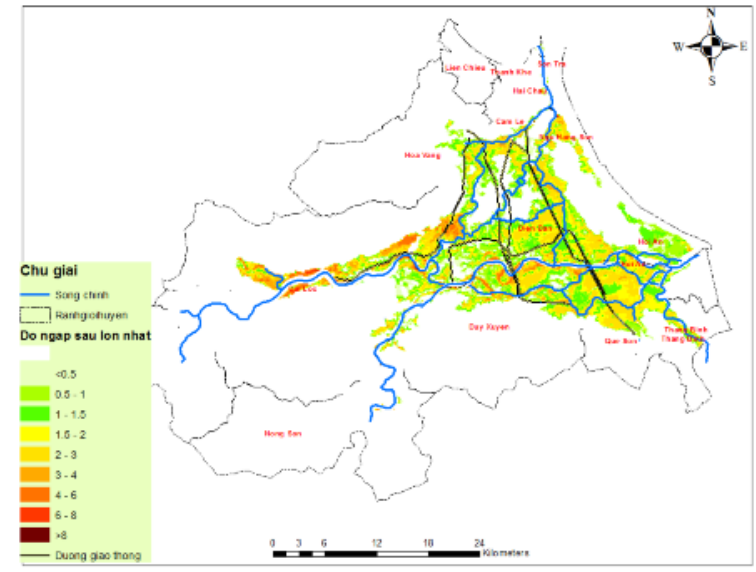

Hình 10. Độngập sâu lớn nhất kịch bản mura tần suất 10\% kết hợp mưc nước biển (MNB) $1 \%(K B 2)$

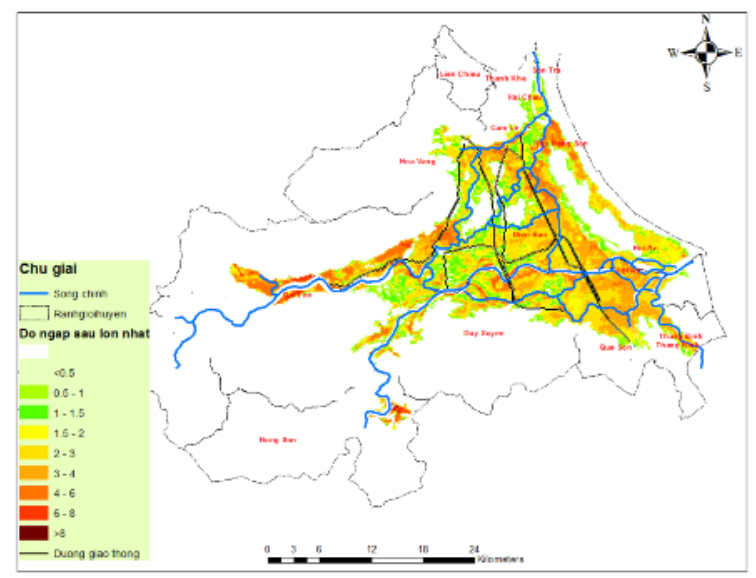

Hình 11. Độ ngập sâu lớn nhất kịch bản mua tần suất $1 \%$ kết hơp mực nước biển (MNB)
Đối với trận mưa có thời kỳ xuất hiện lại là 10 năm kết hợp với mực nước biển 100 năm (KB2).

Đối với trận mưa có thời kỳ xuất hiện lại là 100 năm, độ ngập sâu và diện ngập tăng lên đáng kể (hình 11). Nếu xem xét mực nước tại các trạm khống chế ở hạ lưu, Câu Lâu và Cẩm Lệ (xem hình 2 để xác định vị trí các trạm này), có thể nhận thấy các trận lũ thiết kế được xây dựng có mực nước lớn hơn nhiều so với các cấp báo động (Mực nước $\mathrm{BĐ}$ trong hình 12 và 13 ).

Ngay với trận mưa có thời kỳ xuất hiện lại 2 năm kết hợp với triều cường (RP2), mực nước đỉnh lũ đã vượt báo động 1 ở trạm Câu Lâu và báo động 2 ở trạm Cẩm Lệ. Với trận mưa có thời kỳ xuất hiện lại 5 năm (RP5) và trận mưa có thời kỳ xuất hiện lại 10 năm (RP10), mực nước đã vượt báo động 2 . Trận mưa 20 năm (RP20) mực nước đã vượt báo động 3 và trận mưa lớn hơn 50 năm (RP50 và RP100), mực nước vượt mức lịch sử, đo được năm 2009 và 1964.

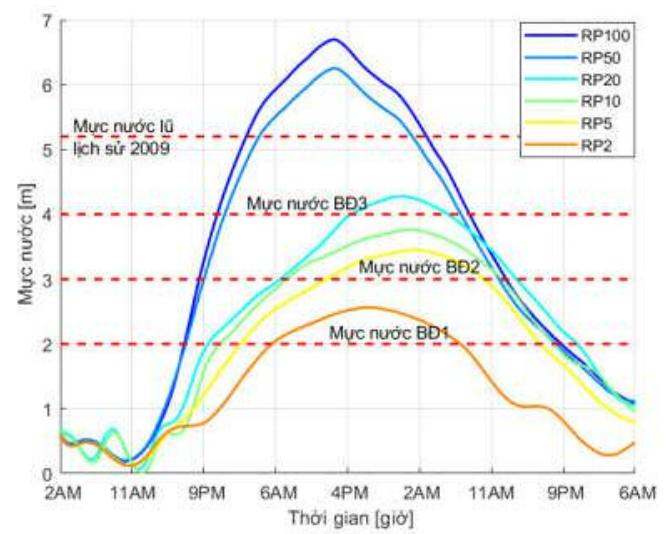

Hình 12. Mực nước lũ trạm Câu Lâu so với các mức báo động tại vị trí này

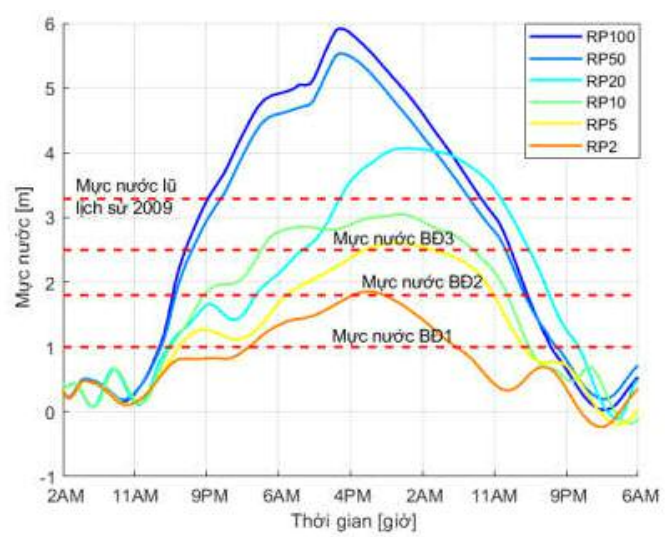

Hình 13. Mực nước lũ trạm Cẩm Lệ so với các mức báo động tại vị trí này 


\section{BÀI BÁO KHOA HỌC}

Nếu chỉ so sánh về diện ngập, có thể nhận thấy diện ngập thay đổi không lớn do địa hình thấp trũng vùng đồng bằng tiếp giáp với địa hình núi cao vùng thượng nguồn lưu vực. Tuy nhiên độ ngập sâu thì tăng lên đáng kể.

Từ các kết quả phân tích trên, tiến hành xây dựng bản đồ hiểm họa lũ lụt vùng nghiên cứu.

\subsection{Xây dụng bản đồ hiểm họa}

Sau khi có số liệu mô phỏng ngập lụt của 5 kịch bản lũ, bản đồ hiểm họa được xây dựng dựa trên bộ tiêu chí ở bảng 2 và được thể hiện ở hình 14.

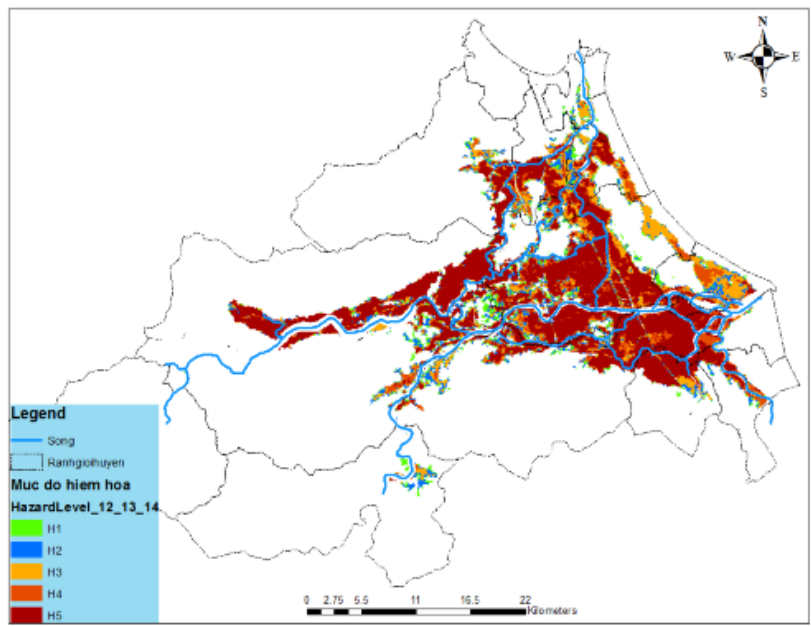

Hình 14. Cấp độ hiểm họa lũ lụt lư lư vục sông Vu Gia Thu Bồn

Huyện có hiểm họa lũ lụt cao nhất là Thăng Bình và Điện Bàn với khoảng $88 \%$ và $70 \%$ diện tích của các huyện nằm trong vùng có hiểm họa trong đó hiểm họa rất cao chiếm hơn $40 \%$. Tiếp đến là Hội $\mathrm{An}$ có tổng diện tích nằm trong vùng hiểm họa lần lượt là $64 \%$ với hiểm họa rất cao chiếm 14\%. Quế Sơn và Duy Xuyên có diện tích hiểm họa chiếm 54\%, Đại Lộc chiếm xấp xỉ $40 \%$. Một số huyện của Đà Nẵng cũng có diện tích chịu hiểm họa tương đối lớn như Cẩm Lệ, Hòa vang, Ngũ hành Sơn với diện tích hiểm họa chiếm trên $40 \%$ trong đó hiểm họa rất cao chiếm khoảng trên dưới $10 \%$.

\section{Kết luận và kiến nghị}

Trong nghiên cứu này, công cụ GIS được kết hợp với mô hình thủy văn, thủy lực MIKE 11 21 để đưa ra được bản đồ hiểm họa lưu vực sông Vu Gia Thu Bồn trong điều kiện hiện trạng. Đây là một trong những đầu vào quan trọng cho nghiên cứu về đánh giá rủi ro lũ lụt vùng nghiên cứu, để từ đó các nhà ra quyết định đưa ra được chiến lược phát triển phù hợp nhằm giảm nhẹ các thiệt hại do nó gây ra, Đối với vùng hạ du lưu vực Vu Gia Thu Bồn, có thể thấy hiểm họa lũ lụt là rất lớn, 7 huyện có hiểm họa ngập lụt cao và rất cao là các huyện Đại Lộc, Điện Bàn, Duy Xuyên, Thăng Bình, Quế Sơn của Quảng Nam và Hòa vang, Ngũ Hành Sơn của Đà Nẵng. Địa hình lưu vực tương đối dốc ở miền núi và thấp và bằng phẳng ở vùng đồng bằng nên diện tích nằm trong vùng có hiểm họa thấp là rất ít.

Dựa vào kết quả này có thể thấy các huyện trên cần có định hướng phát triển cho phù hợp với cấp độ hiểm họa của vùng. Các nghiên cứu tiếp theo nên tập trung phân tích về mức độ phơi lộ và tính dễ bị tổn thương của các cộng đồng nằm trong các vùng hiểm họa. Từ đó đề xuất được các biện pháp giảm thiểu rủi ro lũ lụt cho sự phát triển bền vững cấp lưu vực sông của $\mathrm{Vu}$ Gia Thu Bồn.

Lời cảm ơn: Bài báo này được xây dựng sử dụng kết quả của đề tài cấp cơ sở Truờng Đại học Tài nguyên và Môi truờng Hà Nội "Nghiên cưu xây dựng bản đồ hiểm họa lũ lưu vưc sông Vu Gia Thu Bồn trong điều kiện biến đổi khí hậu” thực hiện bởi chinh tác giả Truong Vân Anh. Phần thiết lập, hiệu chỉnh và kiểm định mô hình được thực hiện bởi tác giả Hoàng Thanh Sơn, Viện Địa lý. 


\section{Tài liệu tham khảo}

1. IPPC (2012), Managing the risks of extreme events and disasters to advance climate change adaptation.

2. Australian Institute for disaster Resilience (2014), Technical flood risk management guideline: Flood hazard.

3. Kundzewicz, Z.W., Kanae, S., Seneviratne, S.I., Handmer, J., Nicholls, N., Peduzzi, P., Mechler, R., Bouwer, L.M., Arnell, N., Mach, K., Wood, R.M., Brakenridge, G.R., Kron, W., Benito, G., Honda, Y., Takahashi, K., Sherstyukov, B., (2014), Flood risk and climate change: global and regional perspectives. Hydrological Sciences Journal, 59 (1), 18, DOI: 10.1080/02626667.2013.857411

4. Spachinger, K., Dorner, W., Metzka, R., Serrhini, K., Fuchs, S., (2008). Flood Risk and Flood hazard maps - Visualisation of hydrological risks. IOP Conference Series: Earth and Environmental Science, 4. 10.1088/1755-1307/4/1/012043.

5. IMHEN (2015), Báo cáo đặc biệt của việt nam về quản lý rủi ro thiên tai và các hiện tuợng cực đoan nhằm thúc đẩy thích ưng với biến đổi khi hậu.

6. VAWR (2017), Rà soát quy hoạch TL sông Vu Gia Thu Bồn.

7. VAWR (2018), Dự án xây dụng bản đồ ngập lụt hạ du hồ chứa VG-TB

8. IG-VAST (2017), Hành lang thoát lũ sông Vu Gia Thu Bồn.

9. VAWR (2016), Xây dựng bản đồ ngập lụt ven biển do nước dâng do bão.

10. Bouwer, L.M., Crompton, R.P., Faust, E. Höppe, P., Pielke Jr, R.A., (2007), Confronting disaster losses. Science, 318, 753.

11. NAWPI, Mô hình MIKE NAM và ứng dụng của nó trong thực tiễn, http://nawapi.gov.vn/index.php?option=com_content\&view=article\&id=3493\%3Amo-hinh-mikenam-va-ng-dng-ca-no-trong-thc-tin\&catid=70\%3 Anhim-v-chuyen-mon-ang-thchin\&Itemid=135\&lang=en

12. DHI (2014), MIKE 11 - A modelling system for Rivers and Channels, Reference manual.

13. DHI (2014), MIKE 21 Flow Model, Hydrodynamic Module, User Guide.

14. DHI (2014), MIKE FLOOD User Manual.

15. Phùng N.X. (2012), Úng Dụng Mô Hình Mike 11 Trong Tính Toán Thuỷ Văn, Thuỷ Lực Mùa Lũ Lưu Vục Sông Ba.

16. "Directive 2007/60/EC of the European Parliament and of the Council of 23 October 2007 on the assessment and management of flood risks."

17. Deltares \& Royal Haskoning 2009, "Best practice guidelines for flood risk assessment" - the Mekong River Commission Secretariat.

18. Hammond, M.J., Chen, A.S., Djordjević, S., Butler, D., Mark, O., (2015), Urban flood impact assessment: A state-of-the-art review, Urban Water Journal, 12 (1), 14-29.

19. Yang, S.H., Pan, Y.W., Dong, J.J., Yeh, K.C., Liao, J.J., (2012), A systematic approach for the assessment of flooding hazard and risk associated with a landslide dam. Natural Hazards, 65 (1), 41 62.

20. Jian, C., Arleen, H., (2007), Modeling urban flood hazard: just how much does dem resolutionmatter?, Conference: Applied Geography Conference (2007), At Indianapolis, IN, Volume: 30, Available at https://www.researchgate.net/figure/Flood-hazard-level-was-then-mapped-for-selectedDEM-resolution-as_tbl1_259582047 (accessed 31 Oct, 2019). 


\title{
BÀI BÁO KHOA HỌC
}

\section{CLASSIFICATION OF FLOOD HAZARD CAUSED BY HEAVY RAIN- FALL AND SEA LEVEL RAISE IN VU GIA THU BON RIVER BASIN}

\author{
Truong Van Anh', Hoang Thanh Son ${ }^{2}$ \\ ${ }^{1}$ Hanoi University of Natural Resources and Environment \\ ${ }^{2}$ Institute of Geography
}

\begin{abstract}
Vu Gia Thu Bon is the biggest river basin in Central part of Vietnam. This basin has very steep mountainous area and sparse river network that make the big volume and intensity of rainwater concentration over large mountainous area and send to the low land of the basin caused huge flooding area with extreme damage to people and asset. Therefore the classification of flood hazard zone will be meaningful work for flood risk management. This paper will classify the flood hazard zone which caused by heavy rainfall in combination with sea level raise in Vugia Thu Bon river basin. The main method is applying modelling and GIS to develop the flood hazard map of the basin. The result show that, 30\% of low land area belongs to very high and high hazard level, 5\% belongs to moderate one and 2\% belongs to low and very low ones. This result will be a basic information for the decision maker who can used it to define a strategic development of region as well as to design an emergency plan for responsing extreme flood event to reduce as much as possible the damage.
\end{abstract}

Keywords: Natural disaster risk assessment, flood hazard, Vu Gia Thu Bon, hazard level. 